\title{
Younger Dryas ice margin retreat in Greenland: new evidence from southwestern Greenland
}

\author{
Svend Funder ${ }^{1}$, Anita H. L. Sørensen ${ }^{2}$, Nicolaj K. Larsen ${ }^{1}$, Anders A. Bjørk ${ }^{3}$, Jason P. Briner ${ }^{4}$, Jesper Olsen ${ }^{5}$, \\ Anders Schomacker ${ }^{6}$, Laura B. Levy ${ }^{7}$, and Kurt H. Kjær ${ }^{1}$ \\ ${ }^{1}$ Globe Institute, University of Copenhagen, 1350 Copenhagen, Denmark \\ ${ }^{2}$ Geosyd, 2730 Copenhagen, Denmark \\ ${ }^{3}$ Department of Geoscience and Natural Resource Management, University of Copenhagen, 1350 Copenhagen, Denmark \\ ${ }^{4}$ Department of Geology, University at Buffalo, Buffalo, NY 14260, USA \\ ${ }^{5}$ Department of Physics and Astronomy, Aarhus University, 8000 Aarhus, Denmark \\ ${ }^{6}$ Department of Geosciences, UiT, the Arctic University of Norway, 9037 Troms $\varnothing$, Norway \\ ${ }^{7}$ Department of Geology, Humboldt State University, 1 Harpst St. Arcata, CA 95521, USA
}

Correspondence: Svend Funder (svf@sund.ku.dk)

Received: 16 April 2020 - Discussion started: 8 May 2020

Revised: 15 January 2021 - Accepted: 28 January 2021 - Published: 4 March 2021

\begin{abstract}
To date the final stage in deglaciation of the Greenland shelf, when a contiguous ice sheet margin on the inner shelf transitioned to outlet glaciers in troughs with intervening ice-free areas, we generated cosmogenic ${ }^{10} \mathrm{Be}$ dates from bedrock knobs on six outlying islands along a stretch of $300 \mathrm{~km}$ of the southwestern Greenland coast. Despite ${ }^{10} \mathrm{Be}$ inheritance influencing some dates, the ages generally support a Greenland Ice Sheet (GrIS) margin that retreated off the inner shelf during the middle Younger Dryas (YD) period. Published ${ }^{10} \mathrm{Be}$ - and ${ }^{14} \mathrm{C}$-dated records show that this history of the GrIS margin is seen in other parts of Greenland but with large variations in the extent and speed of retreat, sometimes even between neighbouring areas. Areas with a chronology extending into the Allerød period show no marked ice margin change at the Allerød-YD transition except in northernmost Greenland. In contrast, landforms on the shelf (moraines and grounding zone wedges) have been suggested to indicate YD readvances or long-lasting ice margin stillstands on the middle shelf. However, these features have been dated primarily by correlation with cold periods in the ice core temperature records. Ice margin retreat during the middle and late YD is explained by advection of warm subsurface water at the ice margin and by increased seasonality. Our results therefore point to the complexity of the climate-ice margin relation and to the urgent need for direct dating of the early deglaciation history of Greenland.
\end{abstract}

\section{Introduction}

The Younger Dryas (YD) cold climate oscillation from 12.8 to $11.7 \mathrm{ka}$ (thousand years before present) began after the Allerød warm period, with a 200-year-long period of cooling, and culminated with a 60-year-long period of abrupt warming, as recorded in Greenland ice cores (Steffensen et al., 2008). Over the Greenland Ice Sheet (GrIS), annual mean temperatures dropped between 5 and $9{ }^{\circ} \mathrm{C}$ (Buizert et al., 2014), when both summer insolation $\left(65^{\circ} \mathrm{N}\right)$ and atmospheric $\mathrm{CO}_{2}$ were increasing (e.g. Buizert et al., 2014). YD climate changes were especially concentrated around the northeastern North Atlantic in the areas of the Atlantic Meridional Overturning Circulation (AMOC) (Carlson, 2013). Similar to present climate change, the YD oscillation was a result of perturbations in the Earth's climate system and, with a view to the future, it is of great interest to study the effect of these climate changes on the margin of the GrIS. During the YD, it seems that the GrIS in most areas had its margin on the shelf, and earlier work concentrated on the behaviour of ice streams in transverse troughs on the shelf (e.g. Larsen et al., 2016); newer references are discussed below.

In this study, we present 18 new cosmogenic ${ }^{10} \mathrm{Be}$ exposure ages from six localities from the inner shelf spanning $300 \mathrm{~km}$ of southwestern Greenland. Our purpose is to shed light on ice margin behaviour during the final phase 
of deglaciation of the shelf when a contiguous GrIS margin transformed into outlet glaciers in transverse troughs feeding the shelf (Fig. 1). Despite field observations that coastal islands experienced warm-based glacial scouring, ${ }^{10} \mathrm{Be}$ inheritance from episodes of earlier exposure influences some samples in our chronology. Still, clustered ages suggest that the GrIS margin generally retreated during the middle YD. These results are discussed in the context of previous studies elsewhere in Greenland, indicating a mismatch between temperature records and ice margin behaviour. Possible mechanisms which may overrule or mute the effect of temperature change in this environment are discussed.

\section{Background}

\subsection{Setting}

The continental shelf in the study area in southwestern Greenland narrows from a width of ca. $70 \mathrm{~km}$ in the north to ca. $50 \mathrm{~km}$ in the south (Fig. 1). It is composed of an inner ca. $25 \mathrm{~km}$ wide and up to $500 \mathrm{~m}$ deep trough running along the coast that is dissected by glacial erosion in Proterozoic orthogneiss bedrock (Henriksen, 2008). On the outer shelf, a belt of shallow banks with a gently undulating surface is composed of younger stratified marine and fluvial sediments. These banks are dissected by 400 to $500 \mathrm{~m}$ deep transverse troughs that are a continuation of the major fjords inland (Holtedahl, 1970; Sommerhoff, 1975; Roksandic, 1979; Sommerhoff, 1981; Ryan et al., 2016). At a distance of $10-15 \mathrm{~km}$ beyond the coast, the inner trough forms an archipelago, with a multitude of small glacially sculptured rocky islands and skerries reflecting intensive but uneven glacial erosion. From these rocky islands we collected our samples (Fig. 2).

\subsection{Deglaciation history}

Although there is little evidence for glacier overriding, it is likely that the ice sheet covered the rather narrow shelf during the LGM (Last Glacial Maximum, ca. $22 \mathrm{ka}$ ); evidence from a marine core in the Davis Strait outside the Fiskenæsset trough suggests that the ice margin here stood at the shelf break until deglaciation began at ca. $18.6 \mathrm{cal}$ ka (Winsor et al., 2015a). By ca. $11 \mathrm{ka}$, the retreating ice margin reached the present coastline, and the subsequent deglaciation of the fjords and land began, as summarized by Winsor et al. (2015b). This leaves a period of ca. 7000 years with the ice margin inland of the shelf edge but otherwise unaccounted for. Possible evidence for a prolonged GrIS margin during this interval includes a series of lobate moraines that run along the troughs and impinge on the inner side of the banks (Fig. 1) (Sommerhoff, 1975; Winsor et al., 2015a). From their setting, these moraines were correlated with the Fiskebanke moraine system to the north (Funder et al., 2011), where they were thought to date from a YD readvance on the shelf (van Tatenhove et al., 1996; Roberts et al., 2009). In our area a limited YD readvance on the inner shelf, the Neria stade, was postulated by Weidick et al. (2004) based on weathering limits on coastal mountains. A YD readvance in this part of the GrIS was also suggested by modelling, which indicated that the ice margin in SW Greenland retreated from the shelf edge to the present coastline in the Bølling-Allerød period but then returned to the shelf during YD (Simpson et al., 2009; Lecavalier et al., 2014). A grounding zone wedge in the Fiskenæsset trough points to a stillstand or readvance of the glacier front at an unknown time during deglaciation (Fig. 1; Ryan et al., 2016). The significance of these features is discussed below in light of our new chronology.

\section{Field and laboratory methods}

Samples were collected from the summits of bedrock knobs in glacially sculpted islands along the inner shelf in southwestern Greenland. Unfortunately, erratic boulders on the bare rock surfaces were largely absent. This potentially represents a problem because while boulders were ideally incorporated into the ice in a pristine condition without previous exposure to cosmic radiation, the glacial erosion of the bedrock surface may not have been deep enough to remove inherited isotopes from older exposures, which may result in overestimation of the age (Briner et al., 2006; Corbett et al., 2013; Larsen et al., 2014). To minimize the risk of inheritance, we selected sites in the lowland, where the overlying ice would have been thickest and most erosive, but above the marine limit to avoid the risk of shielding of the rock surface by the sea. From each site we collected three to four samples within a small radius to be sure that all samples from each locality had been deglaciated at the same time.

Contrary to inheritance, other geologic processes may yield ages that are younger than the true time of exposure. This may occur if a surface has been partially shielded from cosmic radiation by vegetation, snow cover or a veneer of glacial sediments for some time (Gosse and Phillips, 2001). However, it is unlikely that the rocky summits were vegetated, as soil would have been washed into the depressions of the glacial sculpture, which was not observed (Fig. 2). Also, long-lasting and deep snow cover over sample sites is unlikely in the stormy and maritime climate at the outer coast. Indeed, we experienced heavy snowfall during the sampling, with thick snow accumulating in hollows, while the tops were left free of snow (Fig. 2). Topographic shielding from nearby mountains was checked with a clinometer in the field.

The laboratory work comprised sample preparation at the University of Buffalo and measurement of ${ }^{10} \mathrm{Be}$ concentrations at the accelerator mass spectroscopy (AMS) facility at Aarhus University. The laboratory procedure for the preparation followed the University at Buffalo's protocols (Briner, 2015). Samples were crushed and sieved to $250-500 \mu \mathrm{m}$, then exposed to a magnetic separator to remove the more 

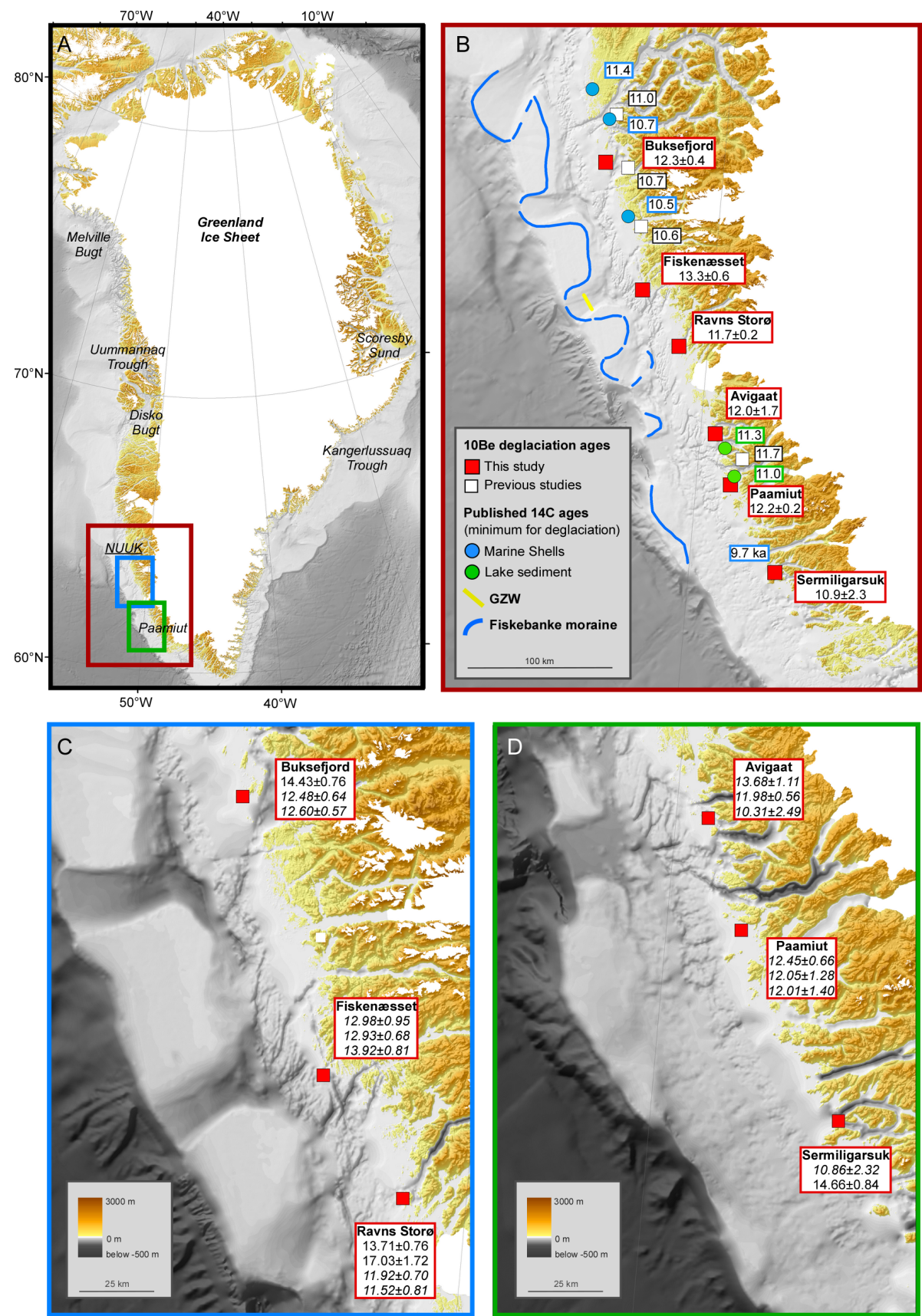

Figure 1. Location of the study area (a). Estimated deglaciation ages and ${ }^{14} \mathrm{C}$ minimum constraints from this work and previous studies (b). Details of the cosmogenic dates from this work and shelf bathymetry $(\mathbf{c}, \mathbf{d})$. For references to previous results, see the text. The background map of Greenland and surrounding seas is from BedMachine Greenland v.3 (Morlighem et al., 2017).

magnetic minerals and facilitate the subsequent froth flotation. In addition to flotation, some samples (X1509, X1513, $\mathrm{X} 1521)$ had to undergo heavy-mineral separation to obtain sufficient amounts of quartz. Before the next step the samples were examined under a microscope to see if they had been substantially purified. Finally, the samples were etched by hydrogen chloride $(\mathrm{HCl})$ and a mixture of hydrofluoric and nitric acid $\left(\mathrm{HF} / \mathrm{NHO}_{3}\right)$ in order to further isolate pure quartz from remaining minerals. Quartz purity was then verified by inductively coupled plasma optical emission spectroscopy at the University of Colorado. Pure quartz samples were fully dissolved with a ${ }^{9} \mathrm{Be}$ carrier, and $\mathrm{Be}(\mathrm{OH})_{2}$ was isolated through column separation. The ${ }^{10} \mathrm{Be} /{ }^{9} \mathrm{Be}$ ratios were measured at the Aarhus AMS Centre (AARAMS), and all samples were blank-corrected (Olsen et al., 2016). Nu- 

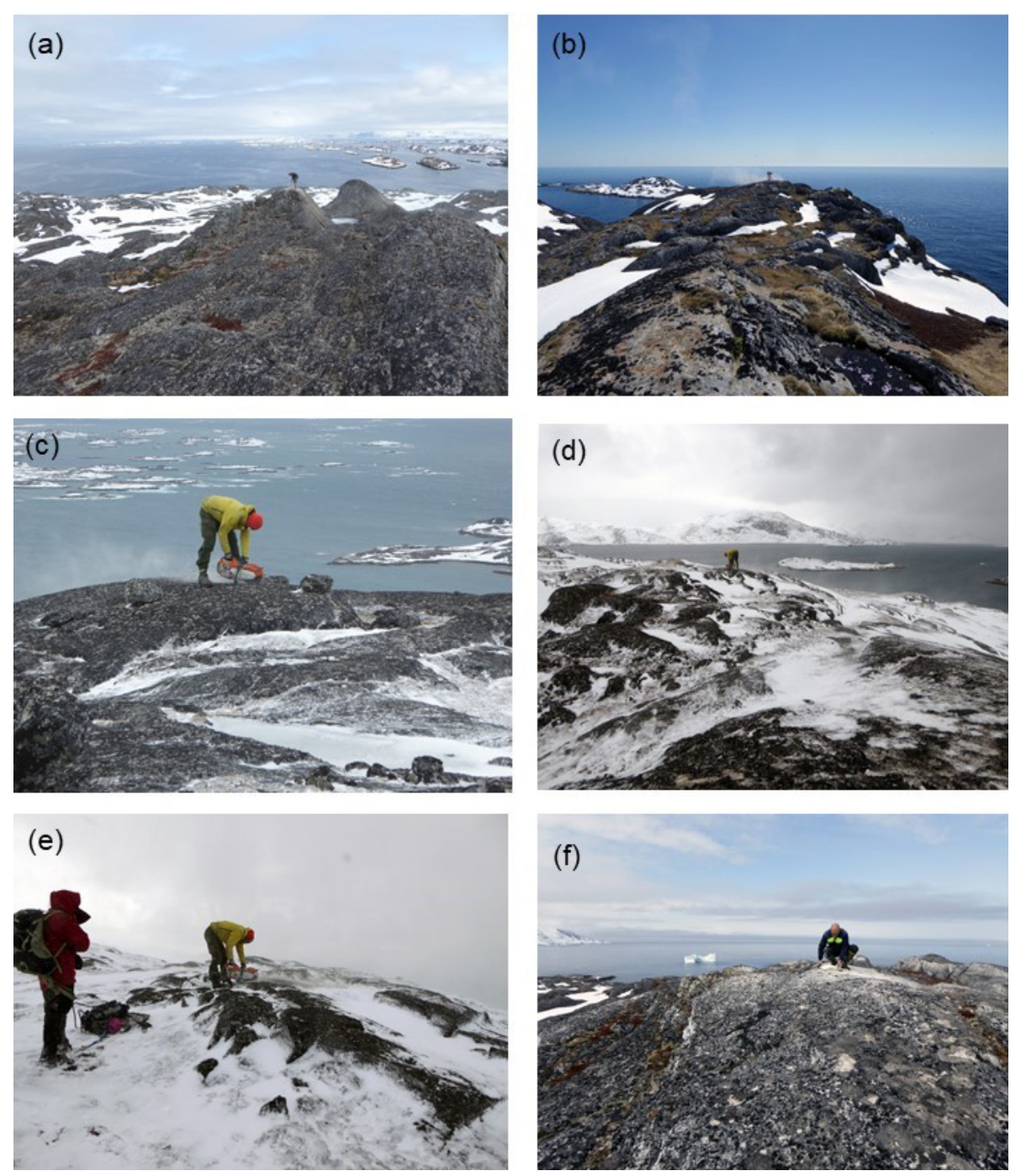

Figure 2. Sampling localities: (a) Buksefjord (sample X1526, $12.0 \mathrm{ka}$ ), (b) Fiskenæsset (sample X1521, 13.0 ka), (c) Ravns Storø (sample X1520, $17.0 \mathrm{ka}$, inheritance), (d) Avigaat (sample X1518, $10.3 \mathrm{ka}$ ), (e) Pamiut (sample X1515, $12.0 \mathrm{ka}$ ), (f) Sermiligarssuk (sample X1507, $10.9 \mathrm{ka})$.

clide concentrations were normalized to the beryllium standard 07KNSTD (Nishiizumi et al., 2007).

The ages were calculated with the CRONUS-Earth online calculator (Balco et al., 2008), using the ${ }^{10} \mathrm{Be} /{ }^{9} \mathrm{Be}$ ratio measured by the AMS subtracted from the processed blank ratio. The processed blank ratio was $2.10 \times 10^{-15}$, and the blank-corrected sample ratios ranged from $0.76 \times 10^{-13}$ to $2.58 \times 10^{-13}$. The Arctic ${ }^{10} \mathrm{Be}$ production rate (Young et al., 2013) and the time-invariant scaling scheme for spallation processes (given by Lal, 1991, and Stone, 2000) were applied. The time-invariant scaling scheme does not incorporate variations in past geomagnetic field strength, but these usually only affect younger samples at ca. $10 \mathrm{ka}$ by $1 \%$ (Nishiizumi et al., 2007). The maximum deviation between different scaling schemes in this material is ca. $1 \%$, so they generally provide consistent ages and do not affect the relative chronology. We used a rock density of $2.65 \mathrm{~g} \mathrm{~cm}^{3}$ and made no correction for potential surface erosion or snow and/or vegetation cover. The study area has undergone glacio-isostatic uplift since the deglaciation, and this may potentially influence the ${ }^{10} \mathrm{Be}$ ages. However, as the production rate calibration dataset probably experienced a similar uplift history at our sample sites, no correction for glacio-isostatic uplift is applied (see Young et al., 2020). Accordingly, we present ${ }^{10} \mathrm{Be}$ ages without correcting for glacio-isostatic uplift, similar to most other ${ }^{10} \mathrm{Be}$ studies from Greenland. Individual ${ }^{10} \mathrm{Be}$ ages are presented with their $1 \sigma$ analytical uncertainties, which include the uncertainty in the blank correction; this is the "internal" uncertainty (Table 1). When we compare our ${ }^{10} \mathrm{Be}$ ages with ${ }^{14} \mathrm{C}$ ages or climate records we include the production rate uncertainty, which is the "external" uncertainty (Balco et al., 2008). 
Table 1. Summary of ${ }^{10} \mathrm{Be}$ data from southwestern Greenland.

\begin{tabular}{|c|c|c|c|c|c|c|c|c|c|c|c|}
\hline $\begin{array}{l}\text { Sample } \\
\text { ID }\end{array}$ & $\begin{array}{l}\text { Latitude } \\
\text { (N) }\end{array}$ & $\begin{array}{l}\text { Longitude } \\
\text { (W) }\end{array}$ & $\begin{array}{l}\text { Elevation } \\
\text { (ma.s.l.) }\end{array}$ & $\begin{array}{l}\text { Sample } \\
\text { type }^{1}\end{array}$ & $\begin{array}{l}\text { Shielding } \\
\text { factor }\end{array}$ & $\begin{array}{l}\text { Thickness } \\
(\mathrm{cm})\end{array}$ & $\begin{array}{l}\text { Quartz } \\
\text { (g) }\end{array}$ & $\begin{array}{l}{ }^{9} \text { Be carrier } \\
\text { weight }(\mathrm{g})\end{array}$ & $\begin{array}{l}{ }^{10} \mathrm{Be} \text { con. } \\
(\text { atoms per } \mathrm{g}) \times 10^{4}\end{array}$ & $\begin{array}{l}{ }^{10} \mathrm{Be} \text { uncert. } \\
\text { (atoms per } \mathrm{g}) \times 10^{4}\end{array}$ & $\begin{array}{l}{ }^{10} \mathrm{Be} \text { age (ka) internal } \\
\text { (external) uncertainties }{ }^{2}\end{array}$ \\
\hline \multicolumn{12}{|c|}{ Buksefjord } \\
\hline X1524 & 63.83957 & 51.73826 & 118 & bedrock & 1 & 4.5 & 40.45 & 0.6067 & 6.88 & 0.36 & $14.43 \pm 0.76(1.03)$ \\
\hline $\mathrm{X} 1525$ & 63.83970 & 51.73851 & 117 & bedrock & 1 & 5.5 & 33.19 & 0.6082 & 5.90 & 0.30 & $12.48 \pm 0.64(0.88)$ \\
\hline \multirow[t]{2}{*}{ X1526 } & 63.83967 & 51.73839 & 102 & bedrock & 1 & 6 & 40.13 & 0.6086 & 5.59 & 0.26 & $12.06 \pm 0.57(0.82)$ \\
\hline & & & & & & \multicolumn{5}{|c|}{ Calculated average (number of samples out of total) } & $12.3 \pm 0.4(n=2 / 3)$ \\
\hline \multicolumn{12}{|c|}{ Fiskenæsset } \\
\hline X1521 & 63.04961 & 50.99505 & 76 & bedrock & 0.99996 & 4.5 & 21.16 & 0.6068 & 5.93 & 0.43 & $12.98 \pm 0.95(1.14)$ \\
\hline $\mathrm{X} 1522$ & 63.05008 & 50.99449 & 75 & bedrock & 0.99997 & 5.5 & 26.75 & 0.6074 & 5.85 & 0.31 & $12.93 \pm 0.68(0.93)$ \\
\hline \multirow[t]{2}{*}{ X1523 } & 63.05016 & 50.99454 & 76 & bedrock & 0.99997 & 5.5 & 36.35 & 0.6049 & 6.31 & 0.36 & $13.92 \pm 0.81(1.05)$ \\
\hline & & & & & & \multicolumn{5}{|c|}{ Calculated average (number of samples out of total) } & $13.3 \pm 0.6(n=3 / 3)$ \\
\hline \multicolumn{12}{|c|}{ Ravns Storø } \\
\hline X1519 & 62.71573 & 50.40947 & 193 & bedrock & 0.99999 & 7 & 35.09 & 0.6074 & 6.95 & 0.38 & $13.71 \pm 0.76(1.01)$ \\
\hline $\mathrm{X} 1520$ & 62.71573 & 50.40947 & 189 & bedrock & 0.99999 & 6 & 45.21 & 0.6083 & 8.66 & 0.87 & $17.03 \pm 1.72(1.91)$ \\
\hline X9364 & 62.71799 & 50.41719 & 209 & bedrock & 1 & 4.5 & 34.47 & 0.6092 & 6.26 & 0.37 & $11.91 \pm 0.70(0.91)$ \\
\hline \multirow[t]{2}{*}{ X9365 } & 62.71770 & 50.41629 & 208 & boulder & 1 & 4.5 & 39.87 & 0.613 & 6.05 & 0.43 & $11.52 \pm 0.81(0.99)$ \\
\hline & & & & & & \multicolumn{5}{|c|}{ Calculated average (number of samples out of total) } & $11.7 \pm 0.4(n=2 / 4)$ \\
\hline \multicolumn{12}{|l|}{ Avigaat } \\
\hline $\mathrm{X} 1516$ & 62.17882 & 49.80153 & 47 & bedrock & 1 & 7 & 45.06 & 0.6062 & 5.94 & 0.48 & $13.68 \pm 1.11(1.29)$ \\
\hline X1517 & 62.17888 & 49.80107 & 44 & bedrock & 1 & 6 & 45.08 & 0.6089 & 5.23 & 0.24 & $11.98 \pm 0.56(0.81)$ \\
\hline \multirow[t]{2}{*}{$\mathrm{X} 1518$} & 62.17894 & 49.80064 & 42 & bedrock & 1 & 4.5 & 45.26 & 0.608 & 4.55 & 1.10 & $10.31 \pm 2.49(2.54)$ \\
\hline & & & & & & \multicolumn{5}{|c|}{ Calculated average (number of samples out of total) } & $12.0 \pm 1.7(n=3 / 3)$ \\
\hline \multicolumn{12}{|l|}{ Paamiut } \\
\hline $\mathrm{X} 1513$ & 61.85744 & 49.53121 & 65 & bedrock & 1 & 6 & 32.31 & 0.6111 & 5.57 & 0.29 & $12.45 \pm 0.66(0.89)$ \\
\hline X1514 & 61.85734 & 49.53098 & 61 & bedrock & 1 & 6.5 & 25.48 & 0.6086 & 5.34 & 0.56 & $12.05 \pm 1.28(1.40)$ \\
\hline \multirow[t]{2}{*}{ X1515 } & 61.85708 & 49.53045 & 60 & bedrock & 1 & 5.5 & 35.44 & 0.607 & 5.36 & 0.62 & $12.01 \pm 1.40(1.52)$ \\
\hline & & & & & & \multicolumn{5}{|c|}{ Calculated average (number of samples out of total) } & $12.2 \pm 0.3(n=3 / 3)$ \\
\hline \multicolumn{12}{|c|}{ Sermiligarsuk } \\
\hline $\mathrm{X} 1507$ & 61.32122 & 48.86104 & 57 & boulder & 0.99967 & 6 & 33.35 & 0.6086 & 4.81 & 1.02 & $10.86 \pm 2.32(2.38)$ \\
\hline \multirow{2}{*}{ X1509 } & 61.32136 & 48.86013 & 61 & bedrock & 0.9997 & 5.5 & 24.76 & 0.5672 & 6.55 & 0.37 & $14.66 \pm 0.84(1.10)$ \\
\hline & & & & & & \multicolumn{5}{|c|}{ Best estimate for deglaciation age } & $10.9 \pm 2.3(n=1 / 1)$ \\
\hline
\end{tabular}

${ }_{1}^{1}$ All samples are coarse-grained orthogneiss. ${ }^{2}$ Italics: used in the average or best estimate (see text).

Previously published ${ }^{14} \mathrm{C}$ ages have been recalibrated using the Intcal20 calibration programme (Reimer et al., 2013). Following the procedure adopted for dates on marine shells from Greenland, ages on marine shells have been corrected with a $\Delta R$ of 0 for western Greenland and with a $\Delta R$ of -150 years for eastern Greenland based on dating modern pre-bomb shells (e.g. Mörner and Funder, 1990), acknowledging that significant, but unknown, changes in the reservoir effect may potentially have affected the ages, especially in the turbulent millennia during the early deglaciation phases (e.g. Andrews et al., 2018).

\section{Results and interpretations}

As discussed below, we consider a spread of old ages to be "inheritance outliers", while the mean of clustered younger ages gives the most reliable deglaciation age. Where there is no overlap between the uncertainties, we regard the youngest age as a maximum age for deglaciation. At each site our new ages are compared to previously published cosmogenic dates of deglaciation or thinning of ice streams at fjord mouths. In addition, we also show ${ }^{14} \mathrm{C}$ results on dating marine molluscs or the onset of organic sedimentation in coastal lakes. Although not dating deglaciation, these dates serve as minimum constraints for local deglaciation. Much of this information has recently been reviewed by Sinclair et al. (2016). The six sites are described below, and the results are shown in Table 1 and Fig. 3.

\subsection{Buksefjord}

This site is located at the outer margin of the strandflat, ca. $15 \mathrm{~km}$ from the main coastline and midway between the mouth of Ameralikfjorden and Buksefjorden (Fig. 1). The three bedrock samples from this locality were collected between 102 and $118 \mathrm{~m}$ a.s.l. and yielded ages of $14.4 \pm 0.8 \mathrm{ka}$ (X1524), $12.5 \pm 0.6 \mathrm{ka}$ (X1525) and $12.1 \pm 0.6 \mathrm{ka}$ (X1526). We interpret the oldest age as an outlier. The two youngest ages have overlapping internal uncertainty and average 


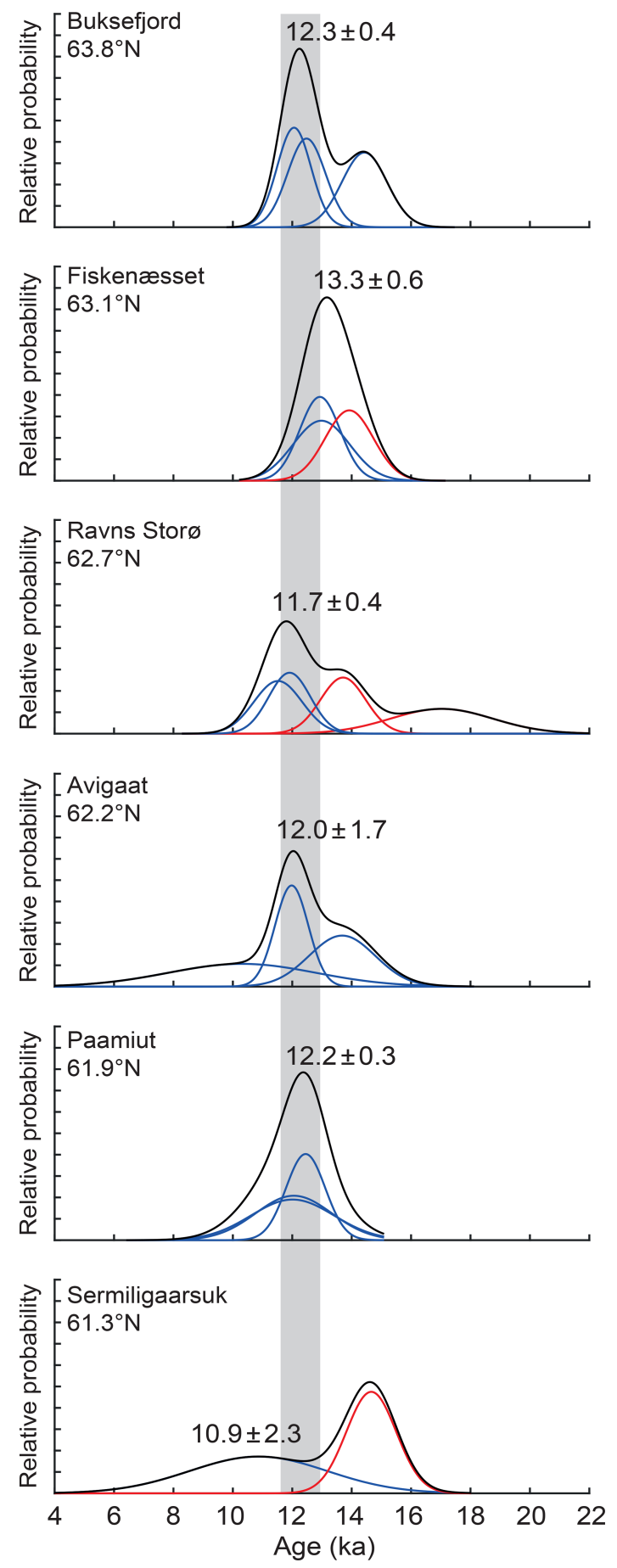

Figure 3. Normal kernel density plots for the $10 \mathrm{Be}$ ages from six coastal sites in SW Greenland. The mean age (black) is calculated based on the individual samples (blue) after excluding statistical outliers (red) (see Table 1).
$12.3 \pm 0.4 \mathrm{ka}$, which we interpret as the time of deglaciation at this site.

On the coastal mountains ca. $10 \mathrm{~km}$ to the east, ${ }^{10} \mathrm{Be}$ dates of boulders from between 82 and $360 \mathrm{~m}$ a.s.l. gave an average deglaciation age of $10.7 \pm 0.6 \mathrm{ka}$ (Larsen et al., 2014). At the mouth of the Nuuk Fjord Complex, $30 \mathrm{~km}$ to the north, marine shells on the outer coast gave a minimum constraint for the deglaciation of 11.4 cal ka (Weidick, 1976a), while ${ }^{10} \mathrm{Be}$ ages close to Nuuk showed deglaciation at ca. $11 \mathrm{ka}$ (Winsor et al., 2015b). This may imply that our dates here are some centuries too old, although the dates from around Nuuk Fjord indicate that the outer coast became ice-free while an ice stream still occupied the Nuuk trough.

\subsection{Fiskenæsset}

Three bedrock samples were collected in the outer archipelago ca. $6 \mathrm{~km}$ from the coast on a small ice-scoured island ca. $15 \mathrm{~km}$ west of the Fiskenæsset settlement (Fig. 1). The samples were collected from $75-76 \mathrm{~m}$ a.s.l and yielded ages of $13.0 \pm 1.0 \mathrm{ka}$ (X1521), $12.9 \pm 0.7 \mathrm{ka}(\mathrm{X} 1522)$ and $13.9 \pm 0.8 \mathrm{ka}$ (X1523). The average, $13.3 \pm 0.6 \mathrm{ka}$, is the oldest deglaciation date of our sites (Fig. 1).

These ages imply that the GrIS margin here was close to the coast prior to the YD. This result should be substantiated by other sources, but there is no available evidence from the adjacent coast to support or oppose this timing of deglaciation. Farther north, at Sermilik Fjord, ${ }^{14} \mathrm{C}$ dates of marine molluscs show that the initial marine transgression and retreat of the GrIS from the outer coast probably did not begin until a short time before $10.5 \mathrm{cal} \mathrm{ka}$, and on coastal mountains nearby, ${ }^{10} \mathrm{Be}$ ages from $450 \mathrm{~m}$ a.s.l. show that the GrIS surface had thinned at ca. $10.6 \mathrm{ka}$ (Larsen et al. 2014). Even though these results come from a different trough, the difference in dates for deglaciation of the coast of 2000 years warrants confirmation (it should be noted that Weidick, 1976b, considered the Sermilik glacier to be the last to retreat from the shelf in this part of Greenland, while the areas to the north and south had already been ice-free for several millennia).

\subsection{Ravns Storø}

Four samples were collected on the island of Ravns Stor $\varnothing$, in the middle of the archipelago, ca. $5 \mathrm{~km}$ from the coast (Fig. 1). The samples were collected between 189 and $209 \mathrm{~m}$ a.s.l. within a radius of $200 \mathrm{~m}$. The ages show a spread of more than 5000 years: $13.7 \pm 0.8 \mathrm{ka}$ (X1519), $17.0 \pm 1.7 \mathrm{ka}(\mathrm{X} 1520), 11.9 \pm 0.7 \mathrm{ka}(\mathrm{X} 9364)$ and $11.5 \pm 0.8 \mathrm{ka}$ (X9365). The two youngest ages, including our only boulder sample (sample X9365), have overlapping internal uncertainties, and we consider their average, $11.7 \pm 0.4 \mathrm{ka}$, to be the best estimate for the time of deglaciation at this site, while the oldest ages are outliers. From this area there is no supporting information on deglaciation history. 


\subsection{Avigaat}

Three samples from the bedrock surface were collected from an islet in the inner archipelago, ca. $3 \mathrm{~km}$ from the coast and the abandoned Avigaat settlement (Fig. 1). The samples were taken between 42 and $47 \mathrm{ma}$ a.s.l. and yield ages of $13.7 \pm 1.1 \mathrm{ka}(\mathrm{X} 1516), 12.0 \pm 0.5 \mathrm{ka}$ (X1517) and $10.3 \pm 2.5 \mathrm{ka}(\mathrm{X} 1518)$. The variable ages and their uncertainties are large. Because these ages overlap, we consider the average of $12.0 \pm 1.7 \mathrm{ka}$ to be the best estimate for deglaciation at this site. Some support for the idea that this might be generally correct comes from a ${ }^{14} \mathrm{C}$ age of ca. $11.3 \mathrm{cal} \mathrm{ka}$ from basal gyttja in a lake in coastal Nerutussoq Fjord to the south (Fig. 1), providing a minimum age for deglaciation at this site (Kelly and Funder, 1974).

\subsection{Paamiut}

This site is located on a small ice-scoured island on the inner archipelago, ca. $5 \mathrm{~km}$ from the coast and close to the mouth of Kuanersoq Fjord and the town of Paamiut (Fig. 1). Here, three bedrock samples between 60 and $65 \mathrm{~m}$ a.s.l. are dated to $12.5 \pm 0.7 \mathrm{X} 1513), 12.1 \pm 1.3$ (X1514) and $12.0 \pm 1.4 \mathrm{ka}$ (X1515). All three ages overlap within the internal uncertainty and average $12.2 \pm 0.3 \mathrm{ka}$.

Around Paamiut and Kuanersoq several studies have supplied both ${ }^{10} \mathrm{Be}$ and ${ }^{14} \mathrm{C}$ deglaciation dates for the outer fjord. As expected, these deglaciation dates from farther inland are somewhat younger than ours. ${ }^{10} \mathrm{Be}$ dates from Kuanersoq indicate thinning of the ice margin in the fjord beginning ca. $11.7 \mathrm{ka}$ and, by extrapolation, retreat from the fjord mouth at ca. $11.2 \mathrm{ka}$ (Winsor et al., 2015b). From a ${ }^{14} \mathrm{C}$ age of $11.0 \mathrm{cal} \mathrm{ka}$ for basal gyttja in a lake $8 \mathrm{~km}$ from our samples and well below the local marine limit, Woodroffe et al. (2014) suggested that deglaciation could not have been much earlier than ca. $11 \mathrm{ka}$. These results from nearby coastal localities therefore indicate deglaciation ca. 1000 years later than at our site. Much of this work concerned the ice stream in Kuanersoq, while our samples come from the open coast to the south, and we suggest that an ice stream in the Kuanersoq trough remained at the inner shelf while the adjacent coastal areas became ice-free.

\subsection{Sermiligaarsuk}

From a small island in the inner archipelago, ca. $2 \mathrm{~km}$ from the coast and $12 \mathrm{~km}$ south of the Sermiligaarsuk Fjord, we collected two samples from 56 and $61 \mathrm{~m}$ a.s.l. One sample is from bedrock (X1509) and one is from a $1 \mathrm{~m}$ diameter boulder (X1507). The two samples have widely scattered ages of $10.9 \pm 2.3 \mathrm{ka}$ (X1507, boulder) and $14.7 \pm 0.8 \mathrm{ka}$ (X1509, bedrock) with large uncertainty, particularly in the boulder age. The oldest age is unrealistic for deglaciation and interpreted as an inheritance outlier. The age of $10.9 \pm 2.3 \mathrm{ka}$ (sample X1507), one of our few boulder dates, is interpreted as a closer approximation for deglaciation at this site. This age is the youngest for deglaciation of the inner shelf, but the island is also closer to the coast than any of the other sites.

Marine shells below the marine limit in the nearby outer Sermiligaarsuk Fjord have an ${ }^{14} \mathrm{C}$ age of $9.7 \mathrm{cal} \mathrm{ka}$, providing a minimum for deglaciation at this site (Weidick et al., 2004).

\section{Discussion}

\subsection{Overview of results from southwestern Greenland}

According to the criteria outlined above, two of the sites, Paamiut (12.2 $\pm 0.2 \mathrm{ka} ; n=3)$ and Fiskenæsset $(13.3 \pm 0.6 \mathrm{ka} ; n=3)$, contain no obvious outliers and hence no obvious inheritance, implying deglaciation ages during the middle YD (Paamiut) and prior to the YD (Fiskenæsset). Also, Avigaat has overlapping uncertainties, indicating deglaciation in late YD times but with large uncertainty. At two sites, Buksefjord and Ravns Storø, one or two samples are interpreted as being influenced by inheritance, but the remaining clusters indicate deglaciation during the middle to late YD. Finally, at Sermiligarssuk only one sample is considered free of inheritance, yielding a best estimate for deglaciation in the early Holocene. From this, the results, although affected by inheritance, would point to deglaciation on the inner shelf in this part of Greenland at varying times between the late Allerød and the early Holocene. However, at some sites the ages are significantly older than expected from a comparison with previous dating of deglaciation at the adjacent coast.

At Paamiut, Fiskenæsset and Buksefjord, our ages are up to 2000 years older than deglaciation ages obtained at nearby fjord mouths. A possible explanation may be that while the coastal areas became ice-free, ice lingered in the major troughs, not reaching the inner shelf until the early Holocene, as shown previously for ice streams in Disko Bugt (Jennings et al., 2014) and suggested by Weidick (1976b) for our area in southwestern Greenland.

However, the offset in deglaciation ages, especially the oldest from Fiskenæsset, could also be impacted by a small amount of uniform inheritance in the bedrock, as demonstrated at Utsira, Norway (Briner et al., 2016). Uniform inheritance may influence the mean age from a cluster, meaning that several bedrock samples from adjacent sites could all have experienced a similar amount of inheritance. This effect is considered to particularly affect bedrock and boulders in areas that experienced long ice-free periods between brief maximum glacial phases (Briner et al., 2016). The landscape in the coastal archipelago is the result of intense erosion by warm-based ice, probably back through several glaciations and during the better part of the last ice age (e.g. Nielsen and Kuijpers, 2013; Seidenkrantz et al., 2019), and we consider the type of deep, uniform inheritance as described by Briner et al. (2016) to be unlikely in our samples.

A possibly more likely type of uniform inheritance could be if the ice margin readvanced but failed to erode the 
bedrock deeply enough to remove the ${ }^{10} \mathrm{Be}$ signal from previous exposure. This could have happened during a YD readvance, as suggested for this area by Weidick et al. (2004) and Lecavalier et al. (2014). However, independent dating is required to show if any of these potential errors have affected the ages, especially those from Fiskenæsset.

In summary, the ${ }^{10} \mathrm{Be}$ dates from the coast of southwestern Greenland, although affected by inheritance, suggest that the ice sheet margin retreated on the inner shelf close to the coast at least from middle to late YD times. Some dates are very old compared to deglaciation dates on the coast. This could be due to differential ice margin behaviour in and away from troughs or, in the case of the oldest age, to ice margin readvance over ice-free land.

\subsection{YD ice margins in Greenland}

From a recent review of YD ice margins in Greenland, Larsen et al. (2016) concluded that ice margin retreat indeed characterized most areas with a dated record going back through or at least into the YD. This is well constrained by ${ }^{10} \mathrm{Be}$ dating in coastal areas and ${ }^{14} \mathrm{C}$-dated marine sediment cores in and outside major cross-shelf troughs, and it applies to areas in western, eastern and southernmost Greenland (Fig. 4). More recently, GrIS retreat during the YD has been corroborated from the Disko Bugt shelf (Hogan et al., 2016; Oksman et al., 2017) and from eastern and southern Greenland (Levy et al., 2016; Andrews et al., 2018; Dyke et al., 2018; Rainsley et al., 2018).

In available records, the most dramatic and studied retreat occurred on the shelf at Disko Bugt, where the ice stream apparently retreated over more than $200 \mathrm{~km}$ from an Allerødearly YD position near the shelf break (Fig. 4), but the retreat was punctuated by periods of topographically conditioned stillstand and a spectacular, but brief, readvance (e.g. O'Cofaigh et al., 2013; Hogan et al., 2016). This is the only readvance dated to the YD in western Greenland and deserves a closer look. The readvance and retreat are recorded by till on the outer shelf and debris flows at the shelf edge. Surprisingly, ${ }^{14} \mathrm{C}$ dates on reworked shell fragments below, within and above the till, as well as in debris flows at the shelf edge, all give overlapping ages. Moreover, mid-shelf in situ shells, which postdate the retreat, also give an overlapping age. This shows that both advance and retreat took place over a very short period. Using the median ages as an indication, Hogan et al. (2016) suggested that retreat from the shelf edge began at ca. $12.24 \mathrm{cal} \mathrm{ka}$ and proceeded until ca. $12.1 \mathrm{cal} \mathrm{ka}$, when the ice margin stabilized in late YD times, and was pinned on mid-shelf topography ca. $150 \mathrm{~km}$ from the shelf edge. This would imply an average retreat rate of ca. $1 \mathrm{~km} \mathrm{yr}^{-1}$, including decade-long stops at several GZWs (grounding zone wedges; see below) on the way. Even considering the large uncertainties in the dates, the retreat rate would be comparable to the highest retreat rates recorded for tidewater glaciers in SE Greenland in recent times (Bjørk et al., 2012) and, as noted by O'Cofaigh et al. (2013), seems irreconcilable with YD temperatures. As a possible explanation O'Cofaigh et al. (2013) tentatively suggested that the advance was a glacio-dynamic surge-like event, when a thin and mobile ice stream confined in the trough advanced to the shelf edge. Whatever the explanation, this singular event is without parallel anywhere in Greenland and is hardly significant for YD climate change.

On the east side of Greenland, in Kangerlussuaq trough and fjord (Fig. 4), not only the shelf, but also most of the fjord became ice-free during YD (e.g. Andrews et al., 2018). It is noteworthy that in these areas, as well as other areas with a record going back to the Allerød (Scoresby Sund, southernmost Greenland), there is no evidence for marked ice margin response to the initial YD cooling. In these two areas, the GrIS had retreated behind the present coastline before YD (e.g. Björck et al., 2002; Larsen et al., 2016; Levy et al., 2016; Levy et al., 2020). Only on the north coast of Greenland did glaciers apparently advance and retreat at the beginning and end of the YD (Larsen et al., 2016).

In areas where the dated record goes back only to the middle YD, such as most of our area, or areas where the ice remained on the shelf until early Preboreal times, as shown by recent cosmogenic dates from coastal southeastern Greenland and the Sisimiut area (Fig. 4) (Dyke et al., 2018; Rainsley et al., 2018; Levy et al., 2020; Young et al., 2020), the ice margin retreat may be seen as a response to the slow warming in the latter portion of the YD (Vacco et al., 2009; Buizert et al., 2018). Therefore, while the dated records going back to Allerød times do not show evidence of ice margin readvance or stillstand at the initial YD cooling, a readvance may have occurred in other areas, considering the large variation in YD ice margin behaviour seen in the dated records. Below we discuss evidence (e.g. landforms on the shelf) which has been attributed to such a YD ice margin readvance or stillstand.

\subsection{YD readvance on the shelf? Moraines and GZWs}

Since their first discovery, the Hellefisk and Fiskebanke moraines on the western Greenland shelf have played a prominent role in the discussion of early deglaciation history (Fig. 4) (e.g. Kelly, 1985; Funder et al., 2011; Hogan et al., 2016). The outermost and oldest, the Hellefisk moraine system, runs along the shelf break for $200 \mathrm{~km}$ at a depth of ca. $200 \mathrm{~m}$, ca. $120 \mathrm{~km}$ from the coast, and consists of swarms of up to $100 \mathrm{~m}$ high ridges (Brett and Zarudski, 1979). To the east of this, halfway towards the coast, the younger Fiskebanke moraines impinge on the inner side of the fishing banks ca. $40 \mathrm{~km}$ from the coast. These are composed of single ridges, which occur intermittently on the inner banks and along the sides of transverse troughs for a distance of ca. $500 \mathrm{~km}$ along the coast (Fig. 4). Although undated, the two moraine systems have generally been regarded as climate signals for two distinct periods of cooling - either Saalian and 


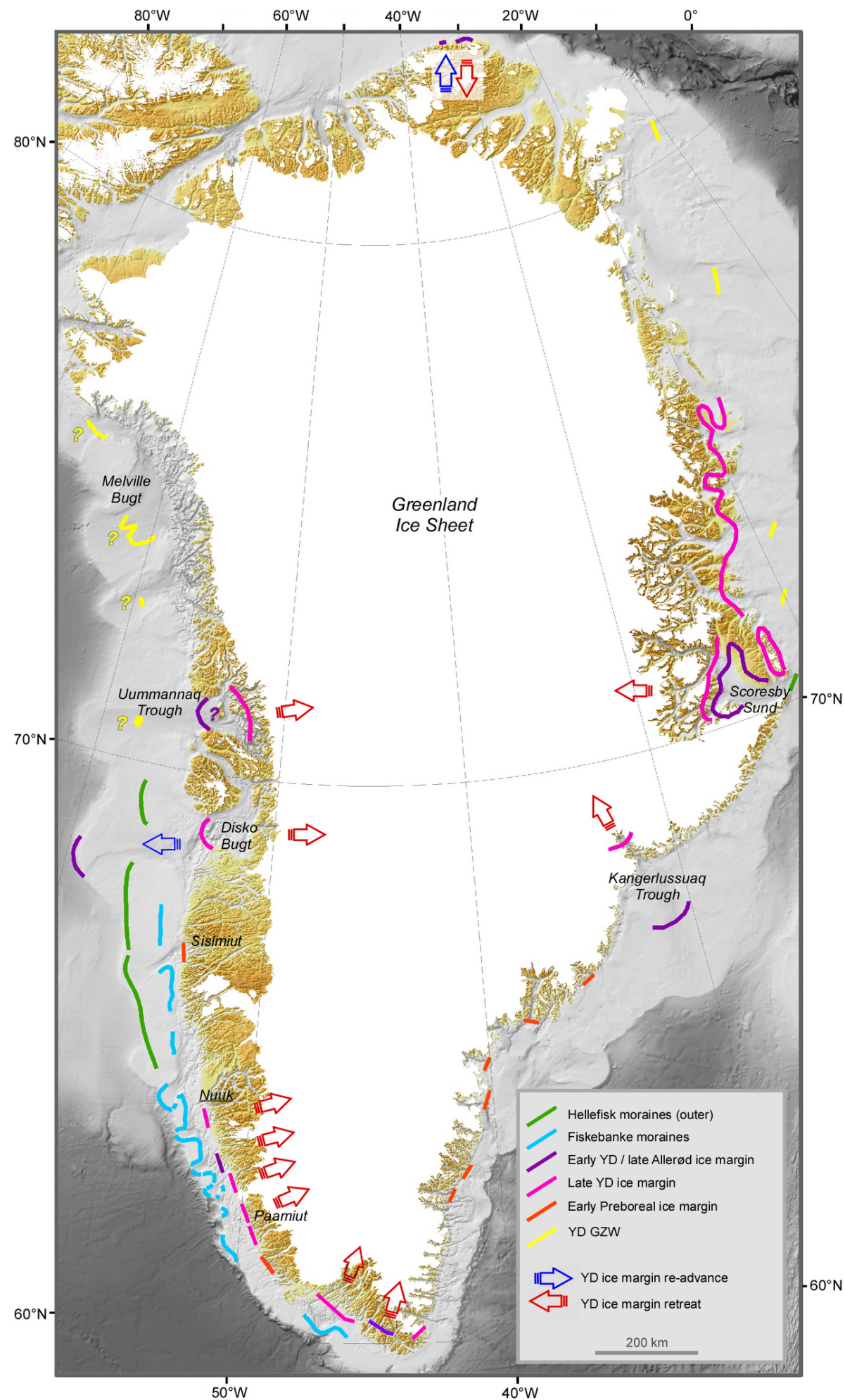

Figure 4. Deglacial ice margin features in Greenland discussed in the text. Question marks at grounding zone wedges apply to age and come from the original literature. Sources are Larsen et al. (2016) and the references discussed in the text. The background map of Greenland and surrounding seas is from BedMachine Greenland v.3 (Morlighem et al., 2017). 
LGM (Funder et al., 2011) or LGM and YD (van Tatenhove et al., 1996; Roberts et al., 2009; Simpson et al., 2009; Lecavalier et al., 2014).

Recently, for the first time, absolute ages have been supplied for parts of the Hellefisk moraines, where Hogan et al. (2016), from ${ }^{14} \mathrm{C}$ dates in marine cores, found that in their study area south of Disko Bugt, these moraines represent a topographically controlled calving bay dated to ca. $12.2 \mathrm{cal} \mathrm{ka}$. In contrast to this, from a marine core at the shelf edge off Nuuk, Seidenkrantz et al. (2019) found that the outer Hellefisk moraine dates to ca. $60 \mathrm{ka}$. These results imply that the outer Hellefisk moraines are not synchronous, but have widely different ages, and are to some extent controlled not by climate but by topography.

Extending for $500 \mathrm{~km}$ along the coast the younger Fiskebanke moraines would be the most compelling evidence for ice margin response to YD cooling in Greenland if they can be dated to YD. The results from Hellefisk moraines may also cast some doubt on the climatic significance of the Fiskebanke moraines. Their affinity to the inner shelf trough and transverse troughs could indicate topographic, rather than climatic, control. As noted above our dates from Fiskenæsset, well behind the moraines, could be interpreted either in favour of or against a YD readvance to the moraines. This stresses the need for climate-independent dating of this important event.

Other geomorphic evidence for YD readvance or longlasting stillstand has recently been suggested from several major transect troughs. This is based on high-resolution multibeam bathymetry, revealing a large variety of glacial landforms that formed during retreat of major ice streams. Notably, the occurrence of large GZWs has been suggested to reflect long-lasting stillstand on the mid-shelf (see references below). GZWs are wedge-shaped sediment accumulations deposited at the front of an ice stream during a period of stability (e.g. Dowdeswell and Fugelli, 2012). GZWs have now been observed in most investigated troughs around Greenland, and, although not dated, prominent GZWs have tentatively been assigned to the YD based on the assumption that they correlate with cold periods in the ice core temperature record (Sheldon et al., 2016; Slabon et al., 2016; Arndt et al., 2017; Newton et al., 2017; Arndt, 2018).

In the Uummannaq trough deglaciation of the shelf began before $15 \mathrm{ka}$, and by ca. $11.5 \mathrm{cal}$ ka the large ice stream in the trough had disintegrated into fjord glaciers with their front close to the present ice margin (e.g. Jennings et al., 2017). However, there are two very different views on what happened in the intervening 3500 years. Based on exposure ages on coastal mountains and ${ }^{14} \mathrm{C}$ dates in the fjords, Roberts et al. (2013) found that the large Uummannaq ice stream had retreated from the trough and into the fjords during the YD, controlled by topography and bathymetry (Fig. 4). In contrast, Sheldon et al. (2016), from a series of marine cores and a prominent GZW in the transect trough, suggested that the ice stream was stabilized for 2000 years from Allerød times on the outer shelf, $150 \mathrm{~km}$ further away from the coast (Fig. 4). This was based on extrapolation from a ${ }^{14} \mathrm{C}$ age and correlation with the ice core temperature record.

An even larger discrepancy between the two dating approaches is seen in northeastern and eastern Greenland, where Arndt et al. (2017) and Arndt (2018) used multibeam bathymetry to interpret lineaments, mid-shelf GZWs and a moraine at the mouth of Scoresby Sund as evidence for readvance of fast-flowing ice streams in major troughs along the northern east coast of Greenland (Fig. 4). These features were attributed to the YD by climatic inference. This overlooks earlier work from land, especially in Scoresby Sund. Here Greenland's highest concentration of ${ }^{10} \mathrm{Be}$ and ${ }^{14} \mathrm{C}$ dates shows that the outlet glaciers in this fjord system had retreated into the fjord during the Allerød, forming a swarm of moraines dating from the Allerød through the YD and into the Preboreal (Denton et al., 2005; Kelly et al., 2008; Hall et al., 2010; Vasskog et al., 2015; Levy et al., 2016), ruling out the possibility of a major YD readvance to or on the shelf,

Similar outbursts of fast-flowing ice streams reaching midshelf GZWs were also recorded farther north in transect troughs at Kong Oscar Fjord, Kejser Franz Joseph Fjord and the wide shelf of northeastern Greenland; these were dated by the same means to the YD (Arndt et al., 2017; Arndt, 2018). It has also been overlooked here that mid-fjord moraines, $100 \mathrm{~km}$ behind the mid-shelf GZWs, have previously been dated to the late YD-earliest Preboreal after calibration of the ${ }^{14} \mathrm{C}$ ages (Hjort, 1979). Reconciling these two datasets would imply an extraordinarily dynamic behaviour of the ice margin along the eastern Greenland seaboard, with both advances and retreats of more than $100 \mathrm{~km}$ within the YD in a period with increased sea ice along the coast (Flückiger et al., 2008; Buizert et al., 2018).

In northwestern Greenland, mid-shelf GZWs with a length of more than $100 \mathrm{~km}$ have been recorded in transect troughs on the shelf in Melville Bugt (Slabon et al., 2016; Newton et al., 2017). From analogy with the "climate-correlated" Uummannaq GZW they were tentatively referred to the YD, although non-climatic bathymetric conditions may have also determined their position (Newton et al., 2017).

In summary, some of the landforms on the shelf, which on climatic grounds have been attributed to YD ice margin readvance or stillstand, apparently do not date from the YD, and surprisingly, none of the ${ }^{14} \mathrm{C}$ - and ${ }^{10} \mathrm{Be}$-dated records show evidence for ice margin response to initial YD cooling (Fig. 4). This highlights the need for climate-independent dating of the submarine landforms and GZWs to exploit this rich source of information and get a better understanding of the ice sheet-climate relation.

\subsection{Ice margin retreat during the YD cold oscillation?}

To explain the mismatch between YD cooling and apparent ice margin retreat, two agents have especially been called on: 
advection of warm oceanic subsurface water to the ice margin and increased climatic seasonality.

In both cases the sequence of events begins with increased production of meltwater around the North Atlantic during the Allerød warm period. The fresher and lighter water eventually sealed off the Atlantic surface circulation from the atmosphere and impeded the Atlantic Meridional Overturning Circulation (AMOC). However, warm water from the subtropical areas was still driven into the North Atlantic but as subsurface currents (Marcott et al., 2011; Ezat et al., 2014). The subsurface water followed the path of the present North Atlantic surface circulation in the Irminger Current running south along southeastern Greenland, continuing around Greenland's southern tip, and heading northwards as the West Greenland Current (Fig. 1). Along the Greenland shelf the warm Atlantic subsurface water was present and caused ice margin retreat in southeastern and western Greenland at $15-16 \mathrm{cal} \mathrm{ka}$, and it was continuously present at the southeastern Greenland shelf edge through Bølling-Allerød and YD times (Kuijpers et al., 2003; Knutz et al., 2011; Jennings et al., 2017; Andrews et al., 2018).

Today warm subsurface water from these currents, below a cap of fresher water, causes extensive melting of floating outlet glaciers in Greenland (e.g. Mayer et al., 2000; Motyka et al., 2011), and during the early phase of deglaciation when the GrIS had its entire margin on the shelf it was especially sensitive to the advection of warm subsurface water, causing ice margin retreat even when temperatures were dropping, as discussed extensively in the literature (Kuijpers et al., 2003; Jennings et al., 2006; Knutz et al., 2011; Rinterknecht et al., 2014; Winsor et al., 2015b; Sheldon et al., 2016; Sinclair et al., 2016; Jennings et al., 2017; Oksman et al., 2017; Andrews et al., 2018; Dyke et al., 2018; Rainsley et al., 2018).

Crucial to the impact of the warm water is the depth of the grounding line at the ice margin and accessibility for the warm subsurface water. This is again dependent on local bathymetry and - in the troughs - on the type of connection to the open ocean, which in each area may control the impact of the warm water on the ice margin, as well as the impact from changing sea level and the presence or absence of buttressing sea ice. This may explain why the deglaciation of the shelf and troughs had such a different character even between neighbouring troughs, such as between the rapid deglaciation of the Kangerlussuaq trough and the much slower deglaciation along the adjacent coast to the south (Dyke et al., 2018). It may also explain the differences in the timing of the onset of deglaciation in the neighbouring Nuussuaq and Disko troughs in western Greenland, as discussed by Jennings et al. (2017).

Increased seasonality is also connected to advection of meltwater over the North Atlantic and a reduced AMOC. The fresher meltwater-diluted water seals off the ocean surface and, especially in winter, cuts off the ocean-atmosphere exchange (Denton et al., 2005; Hall et al., 2008; Vacco et al., 2009; Buizert et al., 2014; Levy et al., 2016; Buizert et al.,
2018). This results in very cold and arid winters and an increase in the extent and duration of sea ice, while summer temperatures - which primarily determine a glacier's mass balance - are less affected and may even warm up (Björck et al., 2002).

Vacco et al. (2009) presented a glaciological model for warm-based glaciers on land, tuned with a temperature record from a Greenland ice core, showing that for areas with high-amplitude change between the Allerød and YD, moraine deposition would be expected at the beginning of the YD, followed by recession of the ice margin in the middle and late YD. This may explain why major YD moraines in Greenland have been seen only in northernmost Greenland and Scoresby Sund - two areas where the glaciers had already become landlocked before the YD, while the ice margin in most other areas retreated on the shelf, controlled to a large extent by warm subsurface ocean circulation.

The importance of changing seasonality has recently been investigated in a model wherein the deglacial ice core temperature records in three ice cores are combined with simulated seasonal air temperatures for the whole of Greenland, enabling assessment of variations in seasonality in time and space (Buizert et al., 2018). The varied seasonality model deviates from previous models (e.g. Lecavalier et al., 2014), indicating that the dramatic temperature changes in the ice core records at the beginning and end of the YD are muted in the varied seasonality model.

In summary, the apparent contradiction between ice core temperature records, wherein temperatures dropped dramatically at the onset of the YD, and the dated glacial record wherein glaciers in many parts retreated, may be explained by the effect of warm subsurface water on the ice margin, which was, all around Greenland, located on the shelf during the early phase of deglaciation. Local topographic and bathymetric conditions controlled the access of warm water to the ice margin when on the shelf. Increased seasonality was due to an increase in the distribution and duration of winter sea ice, and the YD temperature drop in the ice cores was due to a large extent to lowering of winter temperatures with little impact on the ice margin but a large effect on the distribution, thickness and duration of sea ice. This may also explain why neither the rapid initial YD cooling nor the abrupt warming at the end left a clear signal in the dated records.

\section{Conclusions}

${ }^{10} \mathrm{Be}$ dates on bedrock surfaces in the glacially eroded archipelago on the inner shelf of southwestern Greenland are affected by ${ }^{10} \mathrm{Be}$ inherited from earlier exposure, but clustering of ages from each site suggest that the ice margin here was retreating and close to the coast at least from mid-YD times.

A survey of ${ }^{10} \mathrm{Be}$ - and ${ }^{14} \mathrm{C}$-dated records, going back through the YD elsewhere in Greenland to south, east and 
west, shows that the ice margin was also retreating but with large differences in speed and extent even between neighbouring basins, probably controlled by local topography and trough geometry.

While the retreat in our study and in other studies dates from the middle or late YD and may be seen as retreat from an initial YD readvance, areas with a record that goes back into the Allerød show no evidence for ice margin readvance at the initial YD transition. Only in northernmost Greenland did glaciers from a local ice cap apparently advance and retreat at the beginning and end the of YD.

Moraines and GZWs on the shelf, which have been attributed to YD readvance, are dated by climatic inference and need direct age control to distinguish climatic from nonclimatic factors.

The apparent mismatch between the ice core temperature record and the ice margin may be explained by the circumstance that during the LGM, the GrIS, contrary to other large ice sheets, around the whole perimeter was standing on the shelf and especially sensitive to changes in ocean currents, sea level, and sea ice distribution and thickness.

Recently, high-resolution bathymetry has supplied a wealth of data on ice stream dynamics during deglaciation. However, this evidence is essentially dated only by climate inference. To tap this rich source of information and get a better understanding of the ice sheet-climate relation, climate-independent dating of the submarine features is badly needed.

We subscribe to the contention by Andrews et al. (2018, p. 16): "The use of the GrIS's isotopic records as a one-to-one template for coeval changes in glacier and ocean response potentially ignores the different response timescales between the atmosphere, oceans and cryosphere" - also with a bearing on the future.

Code and data availability. The software used for determining ${ }^{10} \mathrm{Be}$ ages and recalibrating older ${ }^{14} \mathrm{C}$ ages is described in the text. All analytical information for the cosmogenic ${ }^{10} \mathrm{Be}$ measurements is listed in the table.

Author contributions. SF, KHK and AAB conceptualized the project and carried out the work in the field. AHLS did the laboratory work, critical assessment and compilation of data under the supervision of and according to methodologies developed by JPB, NKL, AS, LBL and JO. Visualization is thanks to NKL and AAB. The writing and editing were done by SF in close cooperation with NKL and AAB. KHK was responsible for the funding acquisition.

Competing interests. The authors declare that they have no conflict of interest.
Acknowledgements. The fieldwork would not have been possible without generous support from the Danish Navy and the ship HDMS Knud Rasmussen, with its skipper and his extremely helpful and joyful crew. We are grateful for the constructive and insightful comments offered by the referees David Ullman, David Roberts and Nicolas Adams, as well as discussion with Richard Alley.

Financial support. This work is a part of the X_Centuries project funded by the Danish Council for Independent Research (FNU) (grant no. DFF-0602-02526B) and the Centre for GeoGenetics supported by the Danish National Research Foundation (DNRF94). We also acknowledge support by the GeoCenter Denmark ("Multimillennial ice volume changes of the Greenland ice sheet"), all granted to Kurt H. Kjær.

Review statement. This paper was edited by Alberto Reyes and reviewed by David Roberts, David Ullman, and Nicolas Young.

\section{References}

Andrews, J. T., Cabedo-Sanz, P., Jennings, A. E., Olafsdottir, S., Belt, S. T., and Geirsdottir, A.: Sea ice, ice-rafting, and ocean climate across Denmark Strait during rapid deglaciation (similar to $16-12 \mathrm{cal} \mathrm{ka} \mathrm{BP)} \mathrm{of} \mathrm{the} \mathrm{Iceland} \mathrm{and} \mathrm{East} \mathrm{Greenland} \mathrm{shelves,} \mathrm{J.}$ Quaternary Sci., 33, 112-130, 2018.

Arndt, J. E.: Marine geomorphological record of Ice Sheet development in East Greenland since the Last Glacial Maximum, J. Quaternary Sci., 33, 853-864, 2018.

Arndt, J. E., Jokat, W., and Dorschel, B.: The last glaciation and deglaciation of the Northeast Greenland continental shelf revealed by hydro-acoustic data, Quaternary Sci. Rev., 160, 45-56, 2017.

Balco, G., Stone, J. O., Lifton, N. A., and Dunai, T. J.: A complete and easily accessible means of calculating surface exposure ages or erosion rates from ${ }^{10} \mathrm{Be}$ and ${ }^{26} \mathrm{Al}$ measurements, Quaternary Geochronol., 3, 174-195, 2008.

Björck, S., Bennike, O., Rosen, P., Andresen, C. S., Bohncke, S., Kaas, E., and Conley, D.: Anomalously mild Younger Dryas summer conditions in southern Greenland, Geology, 30, 427430, 2002.

Bjørk, A. A., Kjær, K. H., Korsgaard, N. J., Khan, A., Kjeldsen, K. K., Andresen, C., Box, J. E., Larsen, N. K., and Funder, S.: An aerial view of 80 years of climate-related glacier fluctuations in southeast Greenland, Nat. Geosci., 5, 427-432, 2012.

Brett, C. P. and Zarudski, E. F. K.: Project Westmar, a shallow marine geophysical survey on the West Greenland shelf, Geol. Surv. Greenland, 87, 1-27, 1979.

Briner, J.: UB Quartz Cleaning Procedure, University at Buffalo, Buffalo, Ny, 20 pp., 2015.

Briner, J. P., Goehring, B. M., Mangerud, J., and Svendsen, J. I.: The deep accumulation of Be-10 at Utsira, southwestern Norway: Implications for cosmogenic nuclide exposure dating in peripheral ice sheet landscapes, Geophys. Res. Lett., 43, 9121-9129, 2016.

Briner, J. P., Miller, G. H., Davis, P. T., and Finkel, R. C.: Cosmogenic radionuclides from fiord landscapes support differential 
erosion by overriding ice sheets, Geol. Soc. Am. Bull., 118, 406420, 2006

Buizert, C., Gkinis, V., Severinghaus, J. P., He, F., Lecavalier, B. S., Kindler, P., Leuenberger, M., Carlson, A. E., Vinther, B., Masson-Delmotte, V., White, J. W. C., Liu, Z. Y., Otto-Bliesner, B., and Brook, E. J.: Greenland temperature response to climate forcing during the last deglaciation, Science, 345, 1177-1180, 2014

Buizert, C., Keisling, B. A., Box, J. E., He, F., Carlson, A. E., Sinclair, G., and DeConto, R. M.: Greenland-Wide Seasonal Temperatures During the Last Deglaciation, Geophys. Res. Lett., 45, 1905-1914, https://doi.org/10.1002/2017GL075601, 2018.

Carlson, A. E.: The Younger Dryas Climate Event, Enc. Quaternary Sci., 3, 126-134, 2013.

Corbett, L. B., Bierman, P. R., Graly, J. A., Neumann, T. A., and Rood, D. H.: Constraining landscape history and glacial erosivity using paired cosmogenic nuclides in Upernavik, northwest Greenland, Geol. Soc. Am. Bull., 125, 1539-1553, 2013.

Denton, G. H., Alley, R. B., Comer, G. C., and Broecker, W. S.: The role of seasonality in abrupt climate change, Quaternary Sci. Rev., 24, 1159-1182, 2005.

Dowdeswell, J. A. and Fugelli, E. M. G.: The seismic architecture and geometry of grounding-zone wedges formed at the marine margins of past ice sheets, Geol. Soc. Am. Bull., 124, 1750$1761,2012$.

Dyke, L. M., Hughes, A. L., Andresen, C. S., Murray, T., Hiemstra, J. F., Bjørk, A. A., and Rodés, Á.: The deglaciation of coastal areas of southeast Greenland, Holocene, 28, 1535-1544, https://doi.org/10.1177/0959683618777067, 2018.

Ezat, M. M., Rasmussen, T. L., and Groeneveld, J.: Persistent intermediate water warming during cold stadials in the southeastern Nordic seas during the past 65 k.y., Geology, 42, 663-666, 2014.

Flückiger, J., Knutti, R., White, J. W. C., and Renssen, H.: Modeled seasonality of glacial abrupt climate events, Clim Dyn., 31, 633645, 2008.

Funder, S., Kjeldsen, K. K., Kjaer, K. H., and Cofaigh, C. O.: The Greenland Ice Sheet During the Past 300,000 Years: A Review, in: Quaternary Glaciations - Extent and Chronology, 15, 699713,2011

Gosse, J. C. and Phillips, F. M.: Terrestrial in situ cosmogenic nuclides: theory and application, Quaternary Sci. Rev., 20, 14751560, 2001.

Hall, B. L., Baroni, C., and Denton, G. H.: The most extensive Holocene advance in the Stauning Alper, East Greenland, occured in the Little Ice Age, Polar Res., 27, 128-134, 2008.

Hall, B. L., Baroni, C., and Denton, G. H.: Relative sea-level changes, Schuchert Dal, East Greenland, with implications for ice extent in late-glacial and Holocene times, Quaternary Sci. Rev., 29, 3370-3378, 2010.

Henriksen, N.: Geological History of Greenland - Four billion years of earth evolution, Geological Survey of Denmark and Greenland, Copenhagen, 2008.

Hjort, C.: Glaciation in Northern East Greenland during the Late Weichselian and Early Flandrian, Boreas, 8, 281-296, 1979.

Hogan, K. A., Cofaigh, C. O., Jennings, A. E., Dowdeswell, J. A., and Hiemstra, J. F.: Deglaciation of a major palaeo-ice stream in Disko Trough, West Greenland, Quaternary Sci. Rev., 147, 5-26, 2016.
Holtedahl, O.: On Morphology of West Greenland Shelf with General Remarks on Marginal-Channel Problem, Mar. Geol., 8, 155$172,1970$.

Jennings, A. E., Andrews, J. T., Cofaigh, C. O., St Onge, G., Sheldon, C., Belt, S. T., Cabedo-Sanz, P., and Hillaire-Marcel, C.: Ocean forcing of Ice Sheet retreat in central west Greenland from LGM to the early Holocene, Earth Planet. Sc. Lett., 472, 1-13, 2017.

Jennings, A. E., Hald, M., Smith, M., and Andrews, J. T.: Freshwater forcing from the Greenland Ice Sheet during the Younger Dryas: evidence from southeastern Greenland shelf cores, Quaternary Sci. Rev., 25, 282-298, 2006.

Jennings, A. E., Walton, M. E., Cofaigh, C. O., Kilfeather, A., Andrews, J. T., Ortiz, J. D., De Vernal, A., and Dowdeswell, J. A.: Paleoenvironments during Younger Dryas-Early Holocene retreat of the Greenland Ice Sheet from outer Disko Trough, central west Greenland, J. Quaternary Sci., 29, 27-40, 2014.

Kelly, M.: A review of the Quaternary geology of western Greenland, in: Quaternary environments eastern Canadian Arctic, Baffin Bay and western Greenland, edited by: Andrews, J. T., Allen \& Unwin, Boston, USA, 1985.

Kelly, M. and Funder, S.: The pollen stratigraphy of late Quaternary lake sediments of South West Greenland, Geol. Surv. Greenland, 64, 1-26, 1974.

Kelly, M. A., Lowell, T. V., Hall, B. L., Schaefer, J. M., Finkel, R. C., Goehring, B. M., Alley, R. B., and Denton, G. H.: A ${ }^{10} \mathrm{Be}$ chronology of lateglacial and Holocene mountain glaciation in the Scoresby Sund region, east Greenland: implications for seasonality during lateglacial time, Quaternary Sci. Rev., 27, 2273 2282, 2008.

Knutz, P. C., Sicre, M. A., Ebbesen, H., Christiansen, S., and Kuijpers, A.: Multiple-stage deglacial retreat of the southern Greenland Ice Sheet linked with Irminger Current warm water transport, Paleoceanography, 26, PA3204, https://doi.org/10.1029/2010PA002053, 2011

Kuijpers, A., Troelstra, S. R., Prins, M. A., Linthout, K., Akhmetzhanov, A., Bouryak, S., Bachmann, M. F., Lassen, S., Rasmussen, S., and Jensen, J. B.: Late Quaternary sedimentary processes and ocean circulation changes at the Southeast Greenland margin, Mar. Geol., 195, 109-129, 2003.

Lal, D.: Cosmic ray labeling of erosion surfaces: in situ nuclide production rates and erosion models, Earth Planet. Sc. Lett., 104, 424-439, 1991.

Larsen, N. K., Funder, S., Kjaer, K. H., Kjeldsen, K. K., Knudsen, M. F., and Linge, H.: Rapid early Holocene ice retreat in West Greenland, Quaternary Sci. Rev., 92, 310-323, 2014.

Larsen, N. K., Funder, S., Linge, H., Moller, P., Schomacker, A., Fabel, D., Xu, S., and Kjaer, K. H.: A Younger Dryas re-advance of local glaciers in north Greenland, Quaternary Sci. Rev., 147, 47-58, 2016.

Lecavalier, B. S., Milne, G. A., Simpson, M. J. R., Wake, L., Huybrechts, P., Tarasov, L., Kjeldsen, K. K., Funder, S., Long, A. J., Woodroffe, S. A., Dyke, A. S., and Larsen, N. K.: A model of Greenland ice sheet deglaciation based on observations of ice extent and relative sea-level, Quaternary Sci. Rev., 102, 54-84, 2014.

Levy, L. B., Kelly, M. A., Lowell, T. V., Hall, B. L., Howley, J. A., and Smith, C. A.: Coeval fluctuations of the Greenland ice sheet 
and a local glacier, central East Greenland, during late glacial and early Holocene time, Geophys. Res. Lett., 43, 1623-1631, 2016.

Levy, L. B., Larsen, N. K., Knudsen, M. F., Egholm, D. L., Bjørk, A. A., Kjeldsen, K. K., Kelly, M. A., Howley, J. A., Olsen, J., Tikhomirov, D., Zimmerman, S. R. H., and Kjær, K. H.: Multiphased deglaciation of south and southeast Greenland controlled by climate and topographic setting, Quaternary Sci. Rev., 242, 106454, https://doi.org/10.1016/j.quascirev.2020.106454, 2020.

Marcott, S. A., Clark, P. U., Padman, L., Klinkhammer, G. P., Springer, S. R., Liu, Z. Y., Otto-Bliesner, B. L., Carlson, A. E., Ungerer, A., Padman, J., He, F., Cheng, J., and Schmittner, A.: Ice-shelf collapse from subsurface warming as a trigger for Heinrich events, P. Natl. Acad. Sci. USA, 108, 13415-13419, 2011.

Mayer, C., Reeh, N., Jung-Rothenhausler, F., Huybrechts, P., and Oerter, H.: The subglacial cavity and implied dynamics under Nioghalvfjerdsfjorden Glacier, NE-Greenland, Geophys. Res. Lett., 27, 2289-2292, 2000.

Morlighem, M., Williams, C. N., Rignot, E., An, L., Arndt, J. E., Bamber, J. L., Catania, G., Chauche, N., Dowdeswell, J. A., Dorschel, B., Fenty, I., Hogan, K., Howat, I., Hubbard, A., Jakobsson, M., Jordan, T. M., Kjeldsen, K. K., Millan, R., Mayer, L., Mouginot, J., Noel, B. P. Y., O’Cofaigh, C., Palmer, S., Rysgaard, S., Seroussi, H., Siegert, M. J., Slabon, P., Straneo, F., van den Broeke, M. R., Weinrebe, W., Wood, M., and Zinglersen, K. B.: BedMachine v3: Complete Bed Topography and Ocean Bathymetry Mapping of Greenland From Multibeam Echo Sounding Combined With Mass Conservation, Geophys. Res. Lett., 44, 11051-11061, 2017.

Motyka, R. J., Truffer, M., Fahnestock, M., Mortensen, J., Rysgaard, S., and Howat, I.: Submarine melting of the 1985 Jakobshavn Isbrae floating tongue and the triggering of the current retreat, J. Geophys. Res.-Earth, 116, F01007, https://doi.org/10.1029/2009JF001632, 2011.

Mörner, N.-A. and Funder, S.: C-14 dating of samples collected during teh NORQUA 86 expedition, and notes on the marine reservoir effect, Meddelelser om Grønland, 22, 57-59, 1990.

Newton, A. M. W., Knutz, P. C., Huuse, M., Gannon, P., Brocklehurst, S. H., Clausen, O. R., and Gong, Y.: Ice stream reorganization and glacial retreat on the northwest Greenland shelf, Geophys. Res. Lett., 44, 7826-7835, 2017.

Nielsen, T. and Kuijpers, A.: Only 5 southern Greenland shelf edge glaciations since the early Pliocene, Sci. Rep.-UK, 3, 1875-1875, 2013.

Nishiizumi, K., Imamura, M., Caffee, M. W., Southon, J. R., Finkel, R. C., and McAninch, J.: Absolute calibration of ${ }^{10} \mathrm{Be}$ AMS standards, Nucl. Instrum. Meth. B, 258, 403-413, 2007.

O'Cofaigh, C., Dowdeswell, J. A., Jennings, A. E., Hogan, K. A., Kilfeather, A., Hiemstra, J. F., Noormets, R., Evans, J., McCarthy, D. J., Andrews, J. T., Lloyd, J. M., and Moros, M.: An extensive and dynamic ice sheet on the West Greenland shelf during the last glacial cycle, Geology, 41, 219-222, 2013.

Oksman, M., Weckstrom, K., Miettinen, A., Juggins, S., Divine, D. V., Jackson, R., Telford, R., Korsgaard, N. J., and Kucera, M.: Younger Dryas ice margin retreat triggered by ocean surface warming in central-eastern Baffin Bay, Nat. Commun., 8, 1017, https://doi.org/10.1038/s41467-017-01155-6, 2017.

Olsen, J., Tikhomirov, D., Grosen, C., Heinemeier, J., and Klein, M.: Radiocarbon Analysis on the New AARAMS 1MV Tandetron, Radiocarbon, 59, 905-913, 2016.
Rainsley, E., Menviel, L., Fogwill, C. J., Turney, C. S. M., Hughes, A. L. C., and Rood, D. H.: Greenland ice mass loss during the Younger Dryas driven by Atlantic Meridional Overturning Circulation feedbacks, Sci. Rep.-UK, 8, 11307, https://doi.org/10.1038/s41598-018-29226-8, 2018.

Reimer, P. J., Bard, E., Bayliss, J. W., Beck, P. G., Blackwell, C., Bronk Ramsey, C. E., Buck, H., Cheng, R. L., Edwards, M., Friedrich, P. M., Grootes, T. P., Guilderson, H., Haflidason, I., Hajdas, C., Hatté, T. J., Heaton, D. L., Hoffmann, A. G., Hogg, K. A., Hughen, K. F., Kaiser, B., Kromer, S. W., Manning, M., Niu, R. W., Reimer, D. A., Richards, E. M., Scott, J. R., Southon, R. A., Staff, C., Turney, S. M., and van der Plicht, J.: IntCal13 and Marine13 Radiocarbon Age Calibration Curves 0-50,000 Years cal BP, Radiocarbon, 55, 1869-1887, 2013.

Rinterknecht, V., Jomelli, V., Brunstein, D., Favier, V., MassonDelmotte, V., Bourles, D., Leanni, L., and Schlappy, R.: Unstable ice stream in Greenland during the Younger Dryas cold event, Geology, 42, 759-762, 2014.

Roberts, D. H., Long, A. J., Schnabel, C., Davies, B. J., Xu, S., Simpson, M. J. R., and Huybrechts, P.: Ice sheet extent and early deglacial history of the southwestern sector of the Greenland Ice Sheet, Quaternary Sci. Rev., 28, 2760-2773, 2009.

Roberts, D. H., Rea, B. R., Lane, T. P., Schnabel, C., and Rodes, A.: New constraints on Greenland ice sheet dynamics during the last glacial cycle: Evidence from the Uummannaq ice stream system, J. Geophys. Res.-Earth, 118, 519-541, 2013.

Roksandic, M. M.: Geology of the continental shelf off West Greenland between $61^{\circ} 15^{\prime} \mathrm{N}$ and $64^{\circ} 00^{\prime} \mathrm{N}$, Geol. Surv. Greenland, 92, 1-15, 1979.

Ryan, J. C., Dowdeswell, J. A., and Hogan, K. A.: Three cross-shelf troughs on the continental shelf of SW Greenland from Olex data, Atlas of Submarine Glacial Landforms: Modern, Quaternary Ancient, 46, 167-168, 2016.

Seidenkrantz, M. S., Kuijpers, A., Olsen, J., Pearce, C., Lindblom, S., Ploug, J., Przybylo, P., and Snowball, I.: Southwest Greenland shelf glaciation during MIS 4 more extensive than during the Last Glacial Maximum, Sci. Rep.-UK, 9, 15617, https://doi.org/10.1038/s41598-019-51983-3, 2019.

Sheldon, C., Jennings, A., Andrews, J. T., Cofaigh, C. O., Hogan, K., Dowdeswell, J. A., and Seidenkrantz, M. S.: Ice stream retreat following the LGM and onset of the west Greenland current in Uummannaq Trough, west Greenland, Quaternary Sci. Re.v, 147, 27-46, 2016.

Simpson, M. J. R., Milne, G. A., Huybrechts, P., and Long, A. J.: Calibrating a glaciological model of the Greenland ice sheet from the Last Glacial Maximum to present-day using field observations of relative sea level and ice extent, Quaternary Sci. Rev., 28, 1631-1657, 2009.

Sinclair, G., Carlson, A. E., Mix, A. C., Lecavalier, B. S., Milne, G., Mathias, A., Buizert, C., and DeConto, R.: Diachronous retreat of the Greenland ice sheet during the last deglaciation, Quaternary Sci. Rev., 145, 243-258, 2016.

Slabon, P., Dorschel, B., Jokat, W., Myklebust, R., Hebbeln, D., and Gebhardt, C.: Greenland ice sheet retreat history in the northeast Baffin Bay based on high-resolution bathymetry, Quaternary Sci. Rev., 154, 182-198, 2016.

Sommerhoff, G.: Geomorphologische Prozesse in der Labrador und Imingersee. Ein Beitrag zur submarinen Geomorphologie 
einer subpolaren Meeresregion, Polarforschung, 51, 175-191, 1981 (in German).

Sommerhoff, G.: Versuch einer geomorphologischen Gliederung des südwestgrönländischen Kontinentalabhanges, Polarforschung, 45, 87-101, 1975 (in German).

Steffensen, J. P., Andersen, K. K., Bigler, M., Clausen, H. B., DahlJensen, D., Fischer, H., Goto-Azuma, K., Hansson, M., Johnsen, S. J., Jouzel, J., Masson-Delmotte, V., Popp, T., Rasmussen, S. O., Rothlisberger, R., Ruth, U., Stauffer, B., Siggaard-Andersen, M. L., Sveinbjornsdottir, A. E., Svensson, A., and White, J. W. C.: High-resolution Greenland Ice Core data show abrupt climate change happens in few years, Science, 321, 680-684, 2008.

Stone, J. O.: Air pressure and cosmogenic isotope production, J. Geophys. Res. 105, 23753-23759, 2000.

Vacco, D. A., Alley, R. B., and Pollard, D.: Modeling dependence of moraine deposition on climate history: the effect of seasonality, Quaternary Sci. Rev., 28, 639-646, 2009.

van Tatenhove, F. G. M., van der Meer, J. J. M., and Koster, E. A.: Implications for deglaciation chronology from new AMS age determinations in central west Greenland, Quaternary Res., 45, 245-253, 1996.

Vasskog, K., Langebroek, P. M., Andrews, J. T., Nilsen, J. E. O., and Nesje, A.: The Greenland Ice Sheet during the last glacial cycle: Current ice loss and contribution to sea-level rise from a palaeoclimatic perspective, Earth-Sci. Rev., 150, 45-67, 2015.

Weidick, A.: C-14 datings of survey material, carried out in 1975, Rapport Grønlands Geologiske Undersøgelse, 80, 136144, 1976a.
Weidick, A.: Observations on the Quaternary geology in the Fiskenæsset area during the summer of 1973, Rapport Greenlands Geologiske Undersøgelse, 73, 96-99, 1976b.

Weidick, A., Kelly, M., and Bennike, O.: Late Quaternary development of the southern sector of the Greenland Ice Sheet, with particular reference to the Qassimiut lobe, Boreas, 33, 284-299, 2004.

Winsor, K., Carlson, A. E., Welke, B. M., and Reilly, B.: Early deglacial onset of southwestern Greenland ice-sheet retreat on the continental shelf, Quaternary Sci. Rev., 128, 117-126, 2015a.

Winsor, K., Carlson, A. E., Caffee, M. W., and Rood, D. H.: Rapid last-deglacial thinning and retreat of the marine-terminating southwestern Greenland ice sheet, Earth Planet. Sc. Lett., 426, $1-12,2015 b$.

Woodroffe, S. A., Long, A. J., Lecavalier, B. S., Milne, G. A., and Bryant, C. L.: Using relative sea-level data to constrain the deglacial and Holocene history of southern Greenland, Quaternary Sci. Rev., 92, 345-356, 2014.

Young, N. E., Briner, J. P., Miller, G. H., Lesnek, A. J., Crump, S. E., Thomas, E. K., Pendleton, S. L., Cuzzone, J., Lamp, J., Zimmerman, S., Caffee, M., and Schaefer, J. M.: Deglaciation of the Greenland and Laurentide ice sheets interrupted by glacier advance during abrupt coolings, Quaternary Sci. Rev., 229, 106091, https://doi.org/10.1016/j.quascirev.2019.106091, 2020.

Young, N. E., Schaefer, J. M., Briner, J., and Goehring, B.M.: ${ }^{10} \mathrm{Be}$ production-rate calibration for the Arctic, J. Quaternary Sci., 28, 516-526, 2013. 